\title{
Predictors of Exclusive Breast Milk Failure Before Six Months: A Study on Exclusive Breastfeeding in the City of Bogor, West Java, Indonesia
}

\author{
Sri Wahyuni ${ }^{1 *}$ (D) Ni Gusti Made Ayu Agung Budi ${ }^{2}$, Gurid Pramintarto Eko Mulyo ${ }^{3}$ (D) Sri Mulyati ${ }^{1}$, Fauzia Fauzia ${ }^{1}$ (D) \\ ${ }^{1}$ Bogor Midwifery Study Program, Poltekkes Kemenkes Bandung, Bandung, Indonesia; ${ }^{2}$ Midwifery Study Program, Poltekkes \\ Kemenkes Jakarta 3, Jawa Barat, Indonesia; ${ }^{3}$ Department of Nutrition, Poltekkes Kemenkes Bandung, Bandung, Indonesia
}

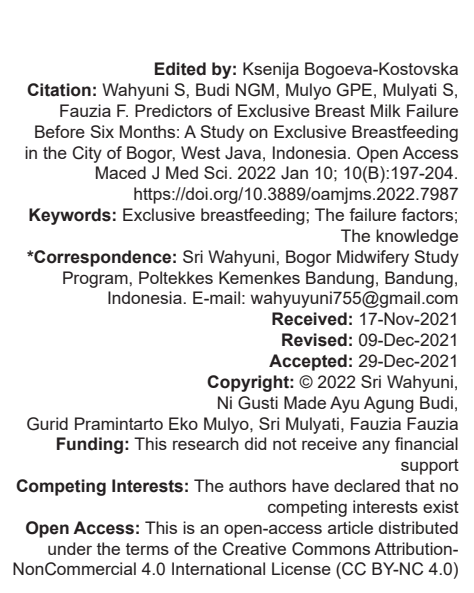

\section{Introduction}

Increasing the rate of exclusive breastfeeding in the first 6 months by at least $50 \%$ is one of the 2025 global nutrition targets, one that we must support and succeed. Interventions to achieve these targets must ensure universal access and establish and involve policies in various areas [1].

Exclusive breastfeeding is the cornerstone of a child's survival and health because it provides essential and irreplaceable nutrients for their growth and development. It is because the nutrients contained in breast milk are the first immunizations for children. Able to protect from respiratory infections, diarrhea and potentially life-threatening diseases and has a long-term effect in the form of protection against obesity and certain non-communicable diseases in the future [2].

\begin{abstract}
BACKGROUND: Exclusive breastfeeding is the cornerstone of a child's survival and health because it provides essential and irreplaceable nutrients for their growth and development. The coverage rate for exclusive breastfeeding

METHODS: The study began with a quasi-experimental period with a pre- and post-test group design approach through a health education process about exclusive breastfeeding in the third trimester of pregnancy, followed by a analysis $\left(\chi^{2}\right)$ and Paired t-test. Then, followed by a qualitative study to explore the supports and barriers to exclusive breastfeeding through in-depth interviews and carried out an analysis with modified Aronso's qualitative analysis steps. The quantitative study sample is 50 people. The sample for the qualitative study was 15 people consisting of mothers RESULTS: The knowledge score of the intervention group increased significantly from 26.08 before the intervention score of the intervention group rose significantly from 8.2 before the intervention to 13.16 after the intervention qualitative study findings contained support and obstacles in implementing exclusive breastfeeding in the city of Bogor. Supporting factors range from a support system in regional regulations and class programs for pregnant internal and external influences.
\end{abstract}

CONCLUSION: Health education can improve knowledge, attitudes and behavior of exclusive breastfeeding. There are still other predictors of the failure of exclusive breastfeeding before 6 months outside of health education. 
The coverage rate for exclusive breastfeeding for infants 0-6 months in West Java in 2017 was $55.4 \%$, which is below the national figure of $61.33 \%$ [6]. Various reasons for this low coverage include inadequate exclusive breastfeeding rates caused by social and cultural factors, health system and commercial factors, and lacking knowledge about breastfeeding [5]. Another reason is that the mother feels that her milk production is insufficient or less [7].

It is in line with research that says that mothers do not exclusively do breastfeeding with inadequate knowledge about infant feeding, unmarried mothers, and lack of access to health services [8]. Another study also said that one of the predictors of breastfeeding was not exclusive because of insufficient milk production due to poor position and attachment and social factors such as the husband and other family members [9].

Health education is believed to increase knowledge and attitudes and behavior of exclusive breastfeeding. There are various obstacles to exclusive breastfeeding, one of which is the lack of prenatal education and inadequate support [10].

It is in line with the research results that the combination of antenatal and early neonatal education, supported by qualified health workers, can increase the number of babies who breastfeed exclusively [11].

\section{Methods}

The study began with a quasi-experimental period with a pre- and post-test group design approach through a health education process about exclusive breastfeeding in the third trimester of pregnancy, followed by a prospective study on the practice of breastfeeding in infants in the first 6 months of life. Then, proceed with qualitative research to explore the support and barriers to exclusive breastfeeding.

\section{Sampling procedure}

The city of Bogor is part of the province of West Java. The population used in the quantitative design was pregnant women in the third trimester (37-42 weeks). Through a random process, three community health center areas were selected as research sites where exclusive the coverage rate of exclusive breastfeeding was below $50 \%$. Respondents were chosen with the criteria of being willing to undergo the research process until delivery and evaluation of breastfeeding for infants until the baby was 6-months-old. The quantitative sample was 50 respondents consisting of 25 in the intervention group and 25 in the control group. While in the qualitative design, the number of informants was 15 people composed of 6 breastfeeding mothers over
6 months both in the post-control group and 6 in the post-intervention group, two midwives working at the Puskesmas, one staff member Health Office from the Bogor City.

\section{Collecting data and conducting research}

\section{The first stage}

To collect data, six trained enumerators assisted the research process from the intervention process, evaluation of breastfeeding for 6 months to interviews in qualitative research.

The study began with a pre-test of knowledge and attitudes in the intervention and control groups. The next step is intervention in health education for pregnant women in the third trimester with the media module in the intervention group and health education with the BUKU KIA (MCH BOOK). The intervention was carried out 3 times with a span between interventions of 2 weeks.

After the intervention period was completed, a post-test of knowledge and attitudes was carried out in the intervention and control groups to see the effectiveness of health education on knowledge and attitudes. The analysis used is Chi-square and Paired t-test analysis.

\section{The second stage}

After the intervention period, the respondent was waited until giving birth, and then an evaluation of exclusive breastfeeding behavior was carried out at the end of each month. The behavioral assessment was carried out by recall by asking respondents about breastfeeding for babies that were carried out during POSYANDU (Integrated service post) activities. If the mother does not come to the POSYANDU, a visit is made to the respondent's house. The recall of exclusive breastfeeding behavior is carried out until the baby is 6-months-old or stopped when the baby is no longer exclusively breastfeeding.

\section{Third stage}

After the quantitative research period is completed, it begins with qualitative research. In-depth interviews were conducted on each sample and then analyzed by modifying the steps of qualitative analysis by Aronso, 1995, namely 1) Collecting data and then transcribing. The author reads the transcript repeatedly. 2) Identifying and summarizing all meanings in the unit or unit of meaning, 3) making codes obtained from the summarized meaning units, 4) Creating subcategories which then unites patterns/fragments of ideas/experiences in categories and finally concludes in the theme. Interviews were conducted in Indonesian. Interviews with breastfeeding mothers were conducted 
at the posyandu and home. Interviews with midwives and health office staff were conducted in the office. The use of source triangulation was not carried out, but various informants strengthened the findings [12]. This research was conducted from March 2017 to September 2018.

\section{Variable definition}

Breastfeeding used in research Terms as recommended by the $\mathrm{WHO}$ the infant receives breast milk (including expressed breast milk or breast milk from a wet nurse) and allows the infant to receive ORS, drops, syrups (vitamins, minerals, medicines), but nothing else [13].

\section{Results}

Univariable analysis to find out the description of each variable descriptively is shown in Table 1.

Table 1: Distribution of respondents by age, education, income, husband's support and marital status

\begin{tabular}{|c|c|c|c|c|}
\hline \multirow[t]{2}{*}{ Variable } & \multicolumn{2}{|c|}{ Intervention } & \multicolumn{2}{|c|}{ Control } \\
\hline & $\mathrm{n}$ & $\%$ & $\mathrm{n}$ & $\%$ \\
\hline \multicolumn{5}{|l|}{ Age } \\
\hline Healthy reproduction & 23 & 92 & 20 & 80 \\
\hline Unhealthy reproduction & 2 & 8 & 5 & 20 \\
\hline \multicolumn{5}{|l|}{ Education } \\
\hline Higt & 14 & 56 & 20 & 80 \\
\hline Low & 11 & 44 & 5 & 20 \\
\hline \multicolumn{5}{|l|}{ Income } \\
\hline Higt & 1 & 4 & 3 & 12 \\
\hline Low & 24 & 96 & 22 & 88 \\
\hline \multicolumn{5}{|l|}{ Husband Support } \\
\hline Yes & 25 & 100 & 24 & 96 \\
\hline No & 0 & 0 & 1 & 4 \\
\hline \multicolumn{5}{|l|}{ Marital Status } \\
\hline Maried & 25 & 100 & 25 & 100 \\
\hline Not Married & 0 & 0 & 0 & 0 \\
\hline
\end{tabular}

Research subjects based on the duration of breastfeeding are shown in Table 2.

Table 2: Distribution of respondents by long of breastfeeding

\begin{tabular}{|c|c|c|c|c|}
\hline \multirow[t]{2}{*}{ Long Breastfeeding } & \multicolumn{2}{|c|}{ Intervention } & \multicolumn{2}{|c|}{ Control } \\
\hline & $\mathrm{n}$ & $\%$ & $\mathrm{n}$ & $\%$ \\
\hline \multicolumn{5}{|l|}{1 Month } \\
\hline Yes & 22 & 88 & 18 & 72 \\
\hline No & 3 & 12 & 7 & 28 \\
\hline \multicolumn{5}{|l|}{2 Month } \\
\hline Yes & 22 & 88 & 12 & 48 \\
\hline No & 3 & 12 & 13 & 52 \\
\hline \multicolumn{5}{|l|}{3 Month } \\
\hline Yes & 18 & 72 & 11 & 44 \\
\hline No & 7 & 28 & 14 & 56 \\
\hline \multicolumn{5}{|l|}{4 Month } \\
\hline Yes & 15 & 60 & 9 & 36 \\
\hline No & 10 & 40 & 16 & 64 \\
\hline \multicolumn{5}{|l|}{5 Month } \\
\hline Yes & 15 & 60 & 5 & 20 \\
\hline No & 10 & 40 & 20 & 80 \\
\hline \multicolumn{5}{|l|}{6 Month } \\
\hline Yes & 9 & 36 & 3 & 12 \\
\hline No & 6 & 64 & 22 & 88 \\
\hline
\end{tabular}

Paired t-test analysis between an intervention (module education) and control of knowledge about exclusive breastfeeding are shown in Table 3.
Table 3: The results of the paired t-test analysis of the provision of education with knowledge of exclusive breastfeeding

\begin{tabular}{llll}
\hline Group & $\mathrm{dy} / \mathrm{dx}$ (marginal effect) & $95 \% \mathrm{Cl}$ & $\mathrm{p}$-value \\
\hline Control (post test vs. pretest) & 3.36 & $1.8-4.9$ & 0.000 \\
Intervenstion (post test vs. pre test) & 5.68 & $3.5-7.8$ & 0.000 \\
Intervensi vs. kontrol & 3.52 & $0.8-6.2$ & 0.14 \\
\hline vs.: Versus & & &
\end{tabular}

Before the intervention, the mother's knowledge score in the intervention group was 26.08 points, increased to 31.76 points, while in the control group, the pre-test data collection was 24.88 points increased during the post-test to 28.24 points. The increase in the knowledge score of the intervention group is 3.52 points higher than the control group. Graph 1 shows the changes in knowledge score in the intervention and control group.

Paired t-test analysis between an intervention (module education) and control of attitude about exclusive breastfeeding are shown in Table 4.

Table 4: The results of the paired t-test analysis of the provision of education with the attitude of exclusive breastfeeding

\begin{tabular}{llll}
\hline Group & dy/da (marginal effect) & $95 \% \mathrm{Cl}$ & $\mathrm{p}$-value \\
\hline Control (post vs. pre) & 3.52 & $2.4-4.6$ & 0.000 \\
Intervention (post vs. Pre) & 4.96 & $3.9-6.0$ & 0.000 \\
Intervention vs. kontrol & 3.1 & $0.9-5.3$ & 0.006 \\
\hline vs.: Versus & & &
\end{tabular}

The mother's attitude score in the intervention group before the intervention was 8.2 points, increased to 13.16 points, while in the control group in the pretest data collection it was 6.52 points in the post-test increased to 10.34

The increase in the attitude score of the intervention group was 3.12 points higher than the control group. Graph 2 shows the changes in attitude score in the intervention and control group.

Bivariable analysis using Chi-square analysis $\left(\chi^{2}\right)$ between respondent characteristics and exclusive breastfeeding behavior are shown in Table 5.

Table 5: The results of the Chi-square test $\left(\chi^{2}\right)$ analysis between characteristics (age, education, income) and exclusive breastfeeding behavior

\begin{tabular}{|c|c|c|c|c|c|}
\hline \multirow[t]{3}{*}{ Characteristics } & \multicolumn{4}{|c|}{ Exclusive Breastfeeding } & \multirow[t]{3}{*}{$\mathrm{p}$-value } \\
\hline & \multicolumn{2}{|c|}{ Yes } & \multicolumn{2}{|c|}{ No } & \\
\hline & $\mathrm{n}$ & $\%$ & $\mathrm{n}$ & $\%$ & \\
\hline \multicolumn{6}{|l|}{ Age } \\
\hline Healthy reproduction & 16 & 64 & 7 & 28 & \multirow[t]{2}{*}{0.120} \\
\hline Unhealthy reproduction & 0 & 0 & 2 & 8 & \\
\hline \multicolumn{6}{|l|}{ Education } \\
\hline Higt & 9 & 36 & 5 & 20 & \multirow[t]{2}{*}{1.000} \\
\hline Low & 7 & 28 & 4 & 16 & \\
\hline \multicolumn{6}{|l|}{ Income } \\
\hline Higt & 0 & 0 & 1 & 4 & \multirow[t]{2}{*}{0.360} \\
\hline Low & 16 & 64 & 8 & 32 & \\
\hline
\end{tabular}

The analysis of the characteristics of respondents with exclusive breastfeeding behavior showed that there was no significant relationship between age and exclusive breastfeeding behavior ( $p$-value of 0.120 ). Table 5 shows no significant relationship between education and exclusive breastfeeding behavior ( $p$-value of 1,000). Table 5 shows no significant relationship between income and 
exclusive breastfeeding behavior ( $p$-value of 0.360 ). Bivariable analysis using Chi-square analysis $\left(\chi^{2}\right)$ between the provision of health education (intervention) education and exclusive breastfeeding behavior are shown in Table 6.

Table 6: The results of the Chi-square test analysis $\left(\chi^{2}\right)$ Providing education (intervention) with exclusive breastfeeding behavior

\begin{tabular}{|c|c|c|c|c|c|}
\hline \multirow[t]{3}{*}{ Group } & \multicolumn{4}{|c|}{ Exclusive Breastfeeding } & \multirow[t]{3}{*}{$\mathrm{p}$-value } \\
\hline & \multicolumn{2}{|c|}{ Yes } & \multicolumn{2}{|l|}{ No } & \\
\hline & $\mathrm{n}$ & $\%$ & $\mathrm{n}$ & $\%$ & \\
\hline Control & 3 & 6 & 22 & 44 & 0.047 \\
\hline Intervention & 16 & 32 & 9 & 18 & \\
\hline
\end{tabular}

Qualitative research analysis was carried out to find out and dig deeper about the support and obstacles in the implementation of exclusive breastfeeding after going through a series of education. The process of analyzing qualitative data can be seen in Tables 7-9.

There are two major themes of this research, namely the description of the factors of support and barriers to exclusive breastfeeding in the city of Bogor. There are four categories of exclusive breastfeeding support, namely (1) Education and Information, (2) Support facilities and infrastructure, (3) Religious values, (4) Local government regulations and health service programs. While the five categories of barriers comprised (1) The effect of shared parenting that does not support exclusive breastfeeding, (2) Lack of social support, (3) Unsustainable health education from health workers (midwives), (4) Lack of motivation and self-confidence.

\section{Support of exclusive breastfeeding}

Information and education during the training play a role in the success of exclusive breastfeeding. "... explained the priority of continuing to breastfeed for up to 6 months..." (Mother of the baby, 25 years). "So you know that breast milk can be expressed and stored..." (Mother of baby, 20-years-old). "Yes, it turns out that breast milk can be stimulated so that it comes out a lot." "(Mother of the baby, 23-years-old)."....."We always recommend giving MPASI after the baby is 6-monthsold" (Midwife, 40 years)

The mother of a 22-year-old baby explains support for facilities and infrastructure in breastfeeding. "I was provided with a refrigerator and a breast pump by my husband." "My place of work allows me to express breast milk and store it...." (Baby's mother, 24-yearsold). "... at the community health centers, a breastfeeding corner is provided" (midwife, 34-years-old).

Religious values also encourage the success of exclusive breastfeeding. "I intend to give this breast milk according to my religion; it says there are many rewards." (Baby's mother, 28 years). "In religion, it is recommended to breastfeed for up to 2 years..." (Mother of the baby, 25 years). "Breastfeeding is an abortive for sin."(Baby's mother, 31 years)

The Bogor City Government Regulation that issues Regional Regulations is a form of support for the exclusive breastfeeding program. "We have a regional regulation on exclusive breastfeeding that we have been running since 2017..." (Bogor City Health Office staff, 46-years-old). In addition to the regional regulations of the City of Bogor, the City of Bogor service also implements a class program for pregnant women where exclusive breastfeeding is emphasized to be implemented. "... we do a class for pregnant women..." "...increasing the coverage of exclusive breastfeeding is one of the main goals..." (Bogor City Health Office staff, 46-years-old). "We have a class for pregnant women..." (Midwife, 34 years).

\section{Barriers to exclusive breastfeeding}

Parenting is done together so that other families give the other baby food. One mother said, "the baby after drinking breast milk is then carried by the grandmother and then given water to drink so that the tongue is not white" (baby's mother, 27 years). External barriers that have a negative impact on the family's failure to provide exclusive breastfeeding include intervention from the baby's aunt and grandmother, who live together or live close. "...sometimes grandma gives coffee to my baby once in a while without asking permission, so the baby doesn't have a seizure when he has a fever..." (baby's mother, 30-years-old). "My baby lives with my aunt and is given bananas when she cries..." (Baby's mother, 27 years).

External barriers in the form of unsupportive social support come from friends and neighbors. "Yes, I like to be advised friends, and also neighbors, just start giving other foods so that the baby gets used to it and

Table 7: Examples of the coding process from meaning units to codes

\begin{tabular}{|c|c|c|c|}
\hline Topic & Meaning units & Condensed meaning units & Codes \\
\hline $\begin{array}{l}\text { What motivates/supports mothers } \\
\text { to breastfeed exclusively? }\end{array}$ & $\begin{array}{l}\text { How do you get information about exclusive breastfeeding? } \\
\text { "When the training explained the importance of continuing to } \\
\text { breastfeed for up to } 6 \text { months, know that breast milk can be } \\
\text { expressed and stored, breast milk can be stimulated so that it } \\
\text { comes out a lot, it is recommended to give breast milk until the } \\
\text { baby is } 6 \text {-months-old." }\end{array}$ & $\begin{array}{l}\text { There is a lot of important information when } \\
\text { participating in the training that encourages } \\
\text { mothers to give exclusive breastfeeding }\end{array}$ & $\begin{array}{l}\text { Beneficial information during } \\
\text { training. } \\
\text { Advised for exclusive } \\
\text { breastfeeding }\end{array}$ \\
\hline $\begin{array}{l}\text { Why is breast milk not } \\
\text { exclusively given until the baby is } \\
6 \text {-months-old? }\end{array}$ & $\begin{array}{l}\text { Failure because grandmothers, aunts and other families who } \\
\text { live in the same house or in the neighborhood like to give water } \\
\text { after the baby is breastfed. Grandma gives coffee to the baby } \\
\text { now and then without asking permission, so the baby doesn't } \\
\text { have a seizure }\end{array}$ & $\begin{array}{l}\text { Parenting that is not entirely in the hands of } \\
\text { the baby's parents. The influence of other } \\
\text { family members who participate in the care } \\
\text { of the baby (Earlier complementary feeding) } \\
\text { Giving drinks other than breast milk to babies } \\
\text { without the mother's consent }\end{array}$ & $\begin{array}{l}\text { Child care together. Babies } \\
\text { are given complementary } \\
\text { foods early by grandmother/ } \\
\text { another family (aunts) without } \\
\text { the permission of the baby's } \\
\text { mother }\end{array}$ \\
\hline
\end{tabular}


Table 8: Example of the coding process from code to subcategory

\begin{tabular}{lll}
\hline Topic & Codes & Subcategory \\
\hline What motivates/supports mothers to breastfeed & Beneficial information during training. & Education and information support during training \\
exclusively? & Advised for exclusive breastfeeding & \\
$\begin{array}{l}\text { Why is breast milk not exclusively given until the } \\
\text { baby is 6-month-old? }\end{array}$ & $\begin{array}{l}\text { Child care together. Babies are given complementary foods early } \\
\text { by grandmother/another family (aunts) without the permission of the } \\
\text { baby's mother }\end{array}$ & $\begin{array}{l}\text { The effect of shared parenting that does not support } \\
\text { exclusive breastfeeding } \\
\text { Negative family influence }\end{array}$ \\
\hline
\end{tabular}

won't be surprised later..." (baby mother, 25-years-old). “...just add formula milk, if you leave it, it won't be too complicated." (baby's mother, 28-years-old).

Counselling on exclusive breastfeeding by health workers is not sustainable. Mothers did attend intervention classes in the form of education about exclusive breastfeeding, but after that, mothers rarely got the motivation to breastfeed exclusively. “...yes. l'll just meet the midwife for a while at the posyandu "I rarely ask questions about breastfeeding..." (Baby's mother, 26-years-old). "Yes ma'am, I rarely get counselling about exclusive breastfeeding anymore..." (Baby's mother, 23-years-old). There is a class for pregnant women that is not continued as a class for breastfeeding mothers so that the breastfeeding process is not motivated by health workers. "...there is a class for pregnant women, but there is no class for breastfeeding mothers..." (Puskesmas midwife, 41-years-old).

Other internal barriers are motivation and a sense of self-confidence that is lacking from the mother. "...yes, when the training was over, I was less motivated to store breast milk..." (Mother of baby, 21-years-old). “...when I go I don't express my milk, I just buy formula, because it's only occasionally..." "...I feel my breast milk is starting to run low, and not enough until my baby is giving additional food..." (baby's mother, age 22 years).

\section{Discussion}

This study seeks to see the factors that cause the failure of exclusive breastfeeding in Bogor after being given education about exclusive breastfeeding. Exclusive breastfeeding is following that the baby only receives breast milk (including expressed breast milk or breast milk from a nursing mother) and allows the baby to receive ORS, drops, syrup (vitamins, minerals, drugs), but nothing else [13].
This study assessed that age, education, and income characteristics had no relationship with exclusive breastfeeding behavior. It is in line with previous research that sociodemographic factors such as maternal education and occupation are not associated with breastfeeding behavior [14].

It is in line with studies conducted by Mekuria and Edris in 2015 that says that the mother's reason for not breastfeeding for the first 6 months of life, including because breastfeeding is not compatible with work because breastfeeding alone is not enough for the baby. They do not have enough milk [15].

This study assessed maternal knowledge, attitudes toward EBF and breastfeeding practices in mothers up to 6 months. Gaps in knowledge, attitude, and practise of exclusive breastfeeding are related to misconceptions about the perception of lack of breast milk to meet the nutritional needs of their children. Most mothers also have inadequate knowledge about the benefits of exclusive breastfeeding. Similar misunderstandings and lack of knowledge have been previously reported [16].

An important finding in this study is that mothers are more confident/more likely to consult with relatives and significant others to address breastfeeding challenges than to consult a health professional. Although consulting with relatives and closest people is not always appropriate and justified because the accuracy and quality of the advice and support provided may not be guaranteed. It follows research even though we have tried to educate the intervention group to build breastfeeding knowledge and attitudes and behavior [15], [16].

There is no significant relationship between age and exclusive breastfeeding behavior; this is in line with research conducted by Fahriani et al. in 2016 that says that age is one of the important factors in pregnancy. The mother's age during pregnancy benefits both the mother and the fetus in the formation of breast milk.

Table 9: Example of the coding process for subcategories to categories and theme

\begin{tabular}{|c|c|c|c|}
\hline Topic & Subcategory & Category & Theme \\
\hline $\begin{array}{l}\text { What motivates/ } \\
\text { supports mothers to } \\
\text { breastfeed exclusively? }\end{array}$ & $\begin{array}{l}\text { Education and information support during training } \\
\text { Support for breast milk pumps and breast milk storage at home and } \\
\text { work } \\
\text { Support religious values } \\
\text { Government regulations on exclusive breastfeeding } \\
\text { Maternity class program }\end{array}$ & $\begin{array}{l}\text { Education and information } \\
\text { Support facilities and infrastructure } \\
\text { Religious values } \\
\text { Local government regulations and health service } \\
\text { programs }\end{array}$ & $\begin{array}{l}\text { Factors of supports to } \\
\text { exclusive } \\
\text { breastfeeding }\end{array}$ \\
\hline $\begin{array}{l}\text { Why is breast milk not } \\
\text { exclusively given until the } \\
\text { baby is } 6 \text {-month-old? }\end{array}$ & $\begin{array}{l}\text { The effect of shared parenting that does not support exclusive } \\
\text { breastfeeding } \\
\text { Negative family influence } \\
\text { The negative influence of neighbors, friends } \\
\text { Lack of continuous information from health workers (midwives) } \\
\text { Give complementary foods early }\end{array}$ & $\begin{array}{l}\text { The effect of shared parenting that does not } \\
\text { support exclusive breastfeeding } \\
\text { Lack of social support } \\
\text { Unsustainable health education from health } \\
\text { workers (midwives) } \\
\text { Lack of motivation and self-confidence }\end{array}$ & $\begin{array}{l}\text { Factors of barriers to } \\
\text { exclusive } \\
\text { breastfeeding }\end{array}$ \\
\hline
\end{tabular}


16-20 years is still considered dangerous even though the risk is less than the previous age. However, mentally and psychologically, it is considered still not mature and mature enough to face the process of childbirth and finally to breastfeed. The age of 20-35 is considered the ideal age to fulfil reproductive tasks, including breastfeeding. Age >35 years is deemed dangerous again because their reproductive health begins to decline, including breastfeeding reproductive work, breast milk production is lower than young people [7].

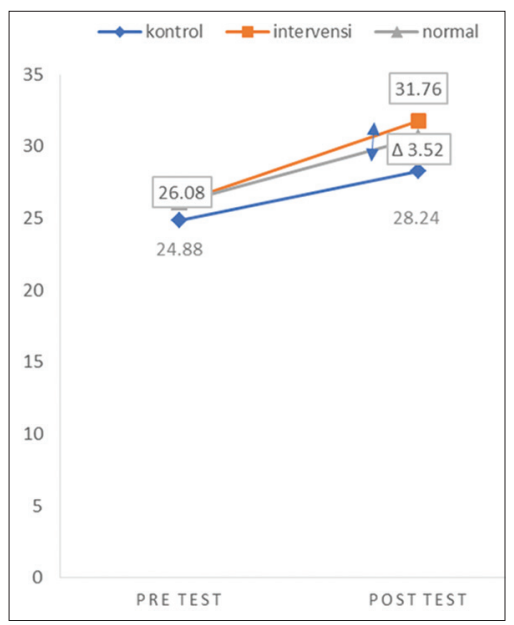

Graph 1: Changes in knowledge score in the intervention and control group

Other studies say that there is no relationship between age and exclusive breastfeeding, even though the mother's age greatly determines maternal health because it is related to the conditions of pregnancy, childbirth and postpartum, and how to care for and breastfeed the baby. Mothers <20-years-old are immature and not physically and socially ready to face pregnancy, especially caring for their babies. While at the healthy reproductive age, also known as adult age, it is hoped that people will be able to solve the problems they face calmly emotionally, especially in caring for their babies [16], [17].

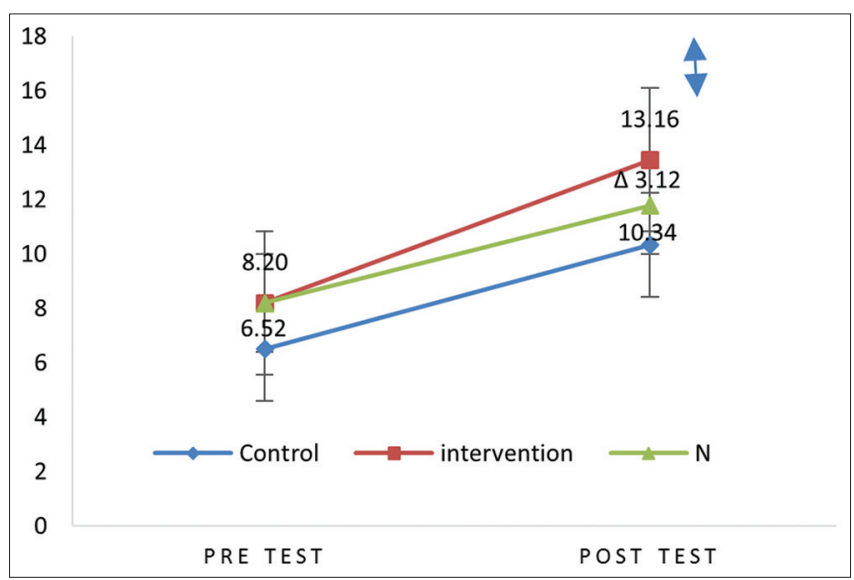

Graph 2: Changes in attitude score in the intervention and control group

There is no significant relationship between education and exclusive breastfeeding where a p-value of 0.634 is obtained. Education level did not affect exclusive breastfeeding for 6 months. This study found that mothers with secondary education were not inferior in seeking knowledge and insight about breastfeeding through internet sites such as social networking communities Facebook, Twitter, and Blackberry groups. Through the social community, they share information about breastfeeding and discuss problems and difficulties during breastfeeding. It is one of the supporting factors for exclusive breastfeeding in the group of mothers with secondary education. It is also in line with other studies conducted by Ansari et al. in 2014 that no significant relationship exists between education and exclusive breastfeeding [7], [17].

In contrast to other studies by Seidu and Stade in 2013 suggesting maternal education level is an important determinant of infant feeding practice in several studies in Ghana, mothers with higher educational levels were less likely to understand and appreciate the benefits of EBF for their infants and were less motivated to practice it [18].

There is no significant relationship between income and exclusive breastfeeding behavior; other studies by Tadesse et al. in 2016 show no relationship between income and exclusive breastfeeding behavior. There is no relationship between family income and exclusive breastfeeding [7], [14].

This study is in line with other studies by Ansari et al. in 2014, which showed that the duration of exclusive breastfeeding in mothers who received education programs increased significantly compared to the control group [17]. Another factor that was found to be related to the practice of exclusive breastfeeding had sufficient knowledge about exclusive breastfeeding. Mothers with higher knowledge give more/exclusively breastfeeding than mothers with lower knowledge [14].

Other studies conducted by Fahriani et al. in 2016 have also shown that mothers' success in breastfeeding their babies is determined by the information received by mothers during the antenatal period. The mother's readiness to breastfeed her baby is also an important factor in increasing her capacity to seek and obtain information about the breastfeeding process [7].

The qualitative study results indicate that several factors cause infants to be given additional food other than breast milk at fewer than 6 months. First, decision-making in infant care is not in the hands of the mother. Second, the lack of unsustainable social and educational support from health workers. Third, the mother's lack of motivation and self-confidence. Research conducted by Dhammika in 2012 says that feeding such as sweetened milk (condensed or emulsified milk), formula milk, or traditional medicine is practised and has become a tradition in Myanmar. At the same time, knowledge about exclusive breastfeeding is relatively high. Perhaps past campaigns about the importance of exclusive breastfeeding led to this high 
level of awareness, but they failed in helping women practise the desired behavior. Despite having high knowledge about exclusive breastfeeding, in practice, mothers introduce several solid foods and liquids before 6 months [19].

Research conducted by Ichsan in 2020 states that various obstacles that cause the failure of exclusive breastfeeding come from multiple levels, namely individuals, families, communities and institutions. For example, lack of motivation, the existence of a parenting pattern that together creates major obstacles from other families, the influence of friends, and formula milk promotion also contribute to the failure of exclusive breastfeeding [20].

Based on the study results, there are two factors that most influence the failure to breastfeed exclusively. First. The influence of parenting and community belief in supporting mixed feeding (babies need additional fluids or solid foods before 6 months because breast milk alone is not enough). Second, aggressive promotion of formula milk, powdered milk and breast milk substitutes. Exclusive. Various reasons why exclusive breastfeeding is also expressed because of the negative sociodemographics of the mother, introducing solid food from an early age as a cultural practice. Much of the reason for the introduction of solids and liquids foods was the belief that solid and liquid foods could make babies more satisfied, healthier, and have higher nutrition [21], [22].

\section{Conclusion}

Health education can improve knowledge, attitudes, and behavior of exclusive breastfeeding. There are other predictors of the failure of exclusive breastfeeding before 6 months outside of health education, namely (1) Decision maker parenting is not in the hands of the mother or both parents, (2) lack of social support, (3) education/education on exclusive breastfeeding by unsustainable health workers (4) Lack of motivation and self-confidence of the mother. Predictors that support exclusive breastfeeding are (1) Information and education during training, (2) Motivation and religious values, (3) Supporting facilities and infrastructure, (4) Regional Government Regulations.

\section{Suggestion}

Health education about the importance of exclusive breastfeeding during pregnancy should be continued with continuous education and motivation throughout the 6-month breastfeeding process. So that efforts to succeed in the 6-month exclusive breastfeeding program can increase significantly. Education and motivation for exclusive breastfeeding for 6 months need to involve family and influential people in caring for the baby.

\section{References}

1. WHO, UNICEF. Global Nutrition Monitoring Framework. Operational Guidance for Tracking Progress in Meeting Targets for 2025. Geneva: World Health Organization; 2017. p. 77. Available from: http://www .apps.who.i nt/iris/ bit stre am/handle/10665/2599 04/9789241513609-eng. pdf;jsessionid=82b08433379c3 e3e69b3f8d4 f 269 0c34? sequence $=1$ [Last accessed on 2021 Nov 01].

2. Bosnjak AP, Grgurić J. Long-term health effects of breast feeding. Lijec Vjesn. 2007;129(8-9):293-8.

PMid:18198630

3. Chika N. Nutritional assessment of exclusively breastfed and non-exclusively breastfed infants Aged (0-6 Months) at mother of christ specialist hospital, Enugu, Nigeria. Int J Nutr Food Sci. 2014;3(5):462.

4. Wu $Q$, Huang $Y$, Liao $Z$, van Velthoven $M H$, Wang $W$, Zhang Y. Effectiveness of WeChat for improving exclusive breastfeeding in Huzhu County China: Randomized controlled trial. J Med Internet Res. 2020;22(12):e23273. https://doi. org/10.2196/23273

PMid:33270026

5. Rozovsky LE. What's at Stake! Dental Practice Management 1988. p. 21-2.

6. Kementerian Kesehatan RI. Profil Kesehatan Indonesia 2014 Vol. 1227. Jakarta, Indonesia: Kementerian Kesehatan RI; 2014. p. 496. Available from: http://www.kemkes.go.id [Last accessed on 2021 Nov 02].

7. Fahriani R, Rohsiswatmo R, Hendarto A. Factors Affecting Exclusive Breastfeeding for Term Infants with Early Initiation of Breastfeeding (IMD). Sari Pediatr. 2016;15(6):394.

8. Egata G, Berhane Y, Worku A. Predictors of nonexclusive breastfeeding at 6 months among rural mothers in east Ethiopia: A community-based analytical crosssectional study. Int Breastfeed J. 2013;8(1):8. https://doi. org/10.1186/1746-4358-8-8

PMid:23919800

9. Sharmin L, Chowdhury MA, Khatun S, Ahmed N. Barriers to exclusive breastfeeding among urban mothers. J Enam Med Coll. 2016;6(2):88-92.

10. Neifert M, Bunik M. Overcoming clinical barriers to exclusive breastfeeding. Pediatr Clin North Am. 2013;60(1):115-45. https://doi.org/10.1016/j.pcl.2012.10.001 PMid:23178062

11. Panaviene J, Zakharchenko L, Olteanu D, Cullen M, El-Khuffash A. Factors contributing to non-exclusive breastfeeding in primigravid mothers. Ir Med J. 2019;112(9):1003. PMid:31651134

12. Aronson J. A pragmatic view of thematic analysis. Qual Rep. 1995;2(1):1-3.

13. WHO and UNICEF. Indicators for Assessing Infant and Young Child Feeding Practices, WHA55 A55. Geneva: WHO, 
UNICEF; 2021. p. 19. Available from: http://www.apps.who. int/iris/bitstream/handle/10665/44306/9789241599290_eng. pdf?sequence $=1$ [Last accessed on 2021 Nov 10].

14. Tadesse T, Mesfin F, Chane T. Prevalence and associated factors of non-exclusive breastfeeding of infants during the first six months in a rural area of Sorro district, Southern Ethiopia: A cross-sectional study. Int Breastfeed J. 2016;11(1):125. https://doi.org/10.1186/s13006-016-0085-6

\section{PMid:27660644}

15. Mekuria G, Edris M. Exclusive breastfeeding and associated factors among mothers in Debre Markos, Northwest Ethiopia: A cross-sectional study. Int Breastfeed J. 2015;10(1):1. https:// doi.org/10.1186/s13006-014-0027-0 PMid:25635183

16. Mogre V, Dery M, Gaa PK. Knowledge, attitudes and determinants of exclusive breastfeeding practice among Ghanaian rural lactating mothers. Int Breastfeed J. 2016;11(1):12. https://doi. org/10.1186/s13006-016-0071-z

PMid:27190546

17. Ansari S, Abedi $P$, Hasanpoor S, Bani $S$. The effect of interventional program on breastfeeding self-efficacy and duration of exclusive breastfeeding in pregnant women in Ahvaz, Iran. Int Sch Res Not. 2014;2014:510793. https://doi. org/10.1155/2014/510793

PMid:27379293

18. Seidu I, Stade R. Exclusive Breastfeeding and Family Influences in Rural Ghana: A Qualitative Study Supervisor; 2013.

19. Dhammika BL, Gunawardena NS. Knowledge, practices and concerns regarding exclusive breastfeeding for six months among mothers of infants in a suburban setting in Sri Lanka. Sri Lanka J Child Health. 2012;41(1):9-14.

20. Ichsan B. Barriers and Support to Exclusive Breastfeeding in Sukoharjo District, Central Java Province, Indonesia: A Qualitative Study; 2020.

21. Thet MM, Khaing EE, Diamond-Smith N, Sudhinaraset M, Oo S, Aung T. Barriers to exclusive breastfeeding in the Ayeyarwaddy Region in Myanmar: Qualitative findings from mothers, grandmothers, and husbands. Appetite. 2016;96:62-9. https:// doi.org/10.1016/j.appet.2015.08.044

PMid:26344810

22. Alianmoghaddam N, Phibbs S, Benn C. Reasons for stopping exclusive breastfeeding between three and six months: A qualitative study. J Pediatr Nurs. 2018;39:37-43. https://doi. org/10.1016/j.pedn.2018.01.007

PMid:29525214 